\title{
RESPONS EMOSIONAL PEMBACA TERHADAP NOVEL SURGA YANG DIRINDUKAN 2 KARYA ASMA NADIA
}

\author{
Herson Kadir, Patrian Pakaya \\ Universitas Negeri Gorontalo \\ hersonung@gmail.com
}

\begin{abstract}
ABSTRAK
Kehadiran karya sastra menjadi berarti dan bernilai, jika ditempuh melalui pengayaan keberagaman tanggapan dan keberterimaan pembaca. Penerimaan dan tanggapan pembaca terhadap karya sastra dapat ditinjau melalui beberapa aspek, salah satunya melalui aspek emosional. Pemahaman terhadap aspek emosional tersebut berperan penting dalam menakar respon pembaca terhadap sebuah karya sastra. Sehubungan dengan hal itu, penelitian ini dilakukan dengan fokus masalah dititikberatkan pada respons emosional pembaca terhadap novel Surga yang Dirindukan 2 karya Asma Nadia. Metode deskriptif analisis digunakan dalam penelitian ini dengan mengandalkan data berupa tanggapan responden terhadap novel, yang hanya ditinjau berdasarkan aspek emosionalnya saja. Sumber data penelitian adalah 15 orang responden yang telah dikategorikan sebagai laki-laki dan perempuan serta dikategorikan sebagai sarjana dan mahasiswa. Data penelitian diperoleh melalui angket yang berisi beberapa pernyataan yang terkait dengan respons emosional pembaca. Penganalisisan data meliputi: (1) pembacaan dan pemahaman secara retroaktif, (2) identifikasi; (3) klasifikasi; (4) analisis dan interpretasi; (5) verifikasi dan penyimpulan hasil analisis sementara respons emosional pembaca terhadap novel Surga yang Dirindukan 2 karya Asma Nadia. Hasil penelitian dan pembahasan menunjukkan adanya perbedaan respons emosional pembaca pada setiap kategori baik laki-laki dan perempuan, maupun kategori sarjana dan mahasiswa. Respons pembaca ditinjau dari aspek emosional ditemukan bahwa, perbedaan tanggapan yang paling dominan terlihat pada unsur kemampuan untuk percaya, keterlibatan, dan suka cita. Pada ketiga unsur lainnya tidak memiliki variasi tanggapan yang berbeda secara signifikan.
\end{abstract}

Kata-kata kunci: novel Surga yang Dirindukan 2, resepsi sastra, respons, emosional, pembaca

\footnotetext{
ABSTRACT

The presence of literary works becomes meaningful and valuable, if pursued through the enrichment of the diversity of responses and acceptance of the reader. The acceptance and response of readers to the literary works can be reviewed through several aspects, one of them through the emotional aspect. Understanding of these emotional aspects plays an important role in measuring the reader's response to a literary work. In this regard, this research is conducted with a focus of the problem focused on the reader's emotional response to the novel of Heaven Desired 2 by Asma Nadia. Descriptive method of analysis used in this study by relying on the data in the form of responses of respondents to the novel, which only reviewed based on emotional aspects only. Sources of research data are 15 respondents who have been categorized as male and female and categorized as
} 
scholars and students. The research data is obtained through a questionnaire containing several statements related to the reader's emotional response. Data analysis includes: (1) retroactive reading and understanding, (2) identification; (3) classification; (4) analysis and interpretation; (5) the verification and inference of the results of the analysis while the reader's emotional response to the novel of Heaven Desired 2 by Asma Nadia. The results of research and discussion show the difference of emotional responses of the reader in each category of both men and women, as well as undergraduate and student categories. The reader's response in terms of the emotional aspects is found that the most dominant response difference is seen in the element of ability to believe, engagement, and joy. On the other three elements do not have significantly different response variations.

Keywords: novel Surga yang Dirindukan, literary receptions

\section{PENDAHULUAN}

Pembaca dan karya sastra saling mempengaruhi satu sama lain. Pembaca berperan sebagai konsumen yang selalu berupaya melahap makna dan nilai yang terkandung di dalam karya sastra. Karya sastra dihadirkan oleh pengarang dalam ruang-ruang pembaca mengemban misi yang bermanfaat dan menghibur. Fungsi sastra dapat menghibur, karena mampu menyentuh aspek emosional pembaca, sehingga dapat memberikan makna estetis terhadap penikmat karya sastra. Di sisi lain sastra dapat pula bermanfaat menyuguhkan pengetahuan, pengalaman, dan perasaan yang disampaikan oleh pengarang kepada pembaca sebagai refleksi terhadap perkembangan kehidupan sosial budaya masyarakat. Setiap persoalan yang diangkat oleh pengarang di dalam karya sastra sering menjadikan karya itu menjadi bermakna dan bernilai, jika telah sampai di tangan pembaca. Peran pembaca menjadi sangat penting, karena semakin banyak karya itu dibaca dan direspons oleh pembaca, maka karya itu dianggap semakin berkualitas. Kualitas sebuah karya sastra dapat diketahui melalui tema-tema besar yang menggambarkan berbagai persoalan fenomanel terjadi di masyarakat. Salah satu persoalan fenomenal yang menjadi isu menarik yang diangkat di dalam novel.

Novel merupakan karya yang berbentuk prosa yang memiliki rangkaian cerita yang mengisahkan kehidupan seseorang dalam hubungannya dengan orang di sekelilingnya dengan tampilan karakter, perwatakan, dan sifat yang berbeda setiap pelaku. Menurut Kuiper (2004:1) novel merupakan seni tulis menulis yang merepresentasikan kehidupan yang dilukiskan secara tersurat dan tersirat. Novel selalu mengekpresikan karakter pengarang yang menyangkut pikiran dan perasaannya yang disampaikan kepada pembaca (Forster,1955:85). Cerita dalam novel selalu ditopang oleh keterjalinan unsur, baik unsur intrinsik maupun ekstrinsik. Hal ini sesuai dengan pandangan Nurgiyantoro (2010:10) bahwa novel merupakan karya fiksi yang dibangun oleh unsur-unsur pembangun, yakni unsur intrinsik dan ekstrinsik. Secara intrinsikalitas cerita dalam novel dibangun oleh keterjalinan beberapa unsur berupa; tema, alur, latar, penokohan, perwatakan, konflik, gaya bahasa, dan amanat. Selain itu, unsur ekstrinsik atau usnur luar karya sastra juga berkontribusi dan mendukung pemaknaan cerita dalam novel. Beberapa unsur luar tersebut dapat berupa segala aspek yang terkait dengan 
persoalan sosial, agama, pendidikan budaya, politik, ekonomi, ilmu pengetahuan dan teknologi, dan lain-lain.

Setiap persoalan yang diangkat di dalam novel selalu bersifat khas dan menarik. Hal itu menjadi daya tarik tersendiri bagi pembaca dan penikmat karya sastra. Cerita dalam novel sangat menggambarkan ungkapan pengetahuan, pengalaman, dan perasaan pengarang. Dengan begitu cerita dalam novel dapat memberikan kesan yang mendalam untuk direspons oleh pembaca. Kesan tersebut dapat bervariasi tergantung tingkat penerimaan emosional setiap pembacanya. Sehubungan dengan hal itu, dapat dinyatakan bahwa untuk dapat merebut makna estetis yang begitu mendalam di dalam sebuah karya, maka perlu dilakukan proses pembacaan. Pembacaan novel pada dasarnya dilakukan sebagai wujud kegiatan apresiasi, evaluasi, dan penilaian terhadap karya sastra. Melalui kegiatan seperti itu, setiap karya sastra yang dibaca dapat menimbulkan tanggapan yang berbedabeda dari responden. Hal itu terjadi karena setiap pembaca atau responden memiliki tingkat penerimaan dan perasaan yang berbeda-beda.

Sebagian besar pembaca sastra lebih senang dan tertarik membaca novel. Oleh sebab itu, dalam konteks tertentu kehadiran sebuah cerita novel akan dianggap berkualitas sangat ditentukan oleh sambutan para pembacanya. Dengan adanya penerimaan dari pembacanya, novel akan memiliki kebermaknaan. Penerimaan secara bermakna itu dapat dikategorikan sebagai bentuk respons atau tanggapan pembaca. Teori yang berhubungan dengan tanggapan pembaca dalam sebuah karya sastra adalah teori resepsi sastra. Resepsi sastra berhubungan dengan sebuah pendekatan dan termasuk salah satu teori sastra yang mengkaji, menelaah, dan memahami, dan meneliti teks sastra dengan mempertimbangkan pembaca selaku pemberi sambutan atau tanggapan. Hal itu sesuai dengan pendapat Pradopo (2013:218) bahwa, resepsi sastra adalah ilmu keindahan yang didasarkan pada tanggapan-tanggapan pembaca terhadap karya sastra. Berbagai tanggapan tersebut dapat dinilai sebagai sebuah keberagaman dan keinginan pembaca.

Model pendekatan resepsi sastra cukup bervariasi. Salah satunya dikembangkan oleh Rien T. Segers yang mengemukakan bahwa aspek inti dalam mengetahui cara penilaian yang dilakukan oleh pembaca yakni melalui aspek intelektual dan aspek emosionalnya (2000:157). Aspek intelektual meliputi sistem sastra yang membentuk karya sastra itu ditambah segi bahasanya. Aspek emosional meliputi proses mental yang terjadi dalam diri pembaca ketika membaca karya sastra seperti daya tarik atau keterkejutan yang dialami pembaca (Widodo dan Ekarini 2009:106). Sehubungan dengan penelitian ini, maka aspek yang akan diteliti berdasarkan kajian resepsi sastra hanya dititikberatkan pada respons emosional pembaca. Indiktaor aspek emosional pembaca yang akan diteliti berupa; (1) keterlibatan (membawa pembaca kepada satu jenis keterlibatan pribadi, baik watak maupun tindakan), (2) emosi (mempunyai dampak pada emosi pembaca), (3) minat (cukup menarik untuk membawa pembaca ke analisis lebih lanjut), (4) keaslian (memberi perspetif yang segar dan berbeda kepada pembaca), (5) suka cita (membangkitkan ketegangan tertentu di hati pembaca), dan (6) kemampuan untuk percaya (dapat dipercaya oleh pembaca). Deskripsi keenam unsur dari aspek emosional tersebut dituangkan dalam sebuah kuesioner yang akan dipakai untuk meneliti respons pembaca terhadap novel. 
Novel yang diteliti adalah novel Surga yang Dirindukan 2 karya asma Nadia. Novel ini menarik untuk diteliti karena ceritanya menyuguhkan persoalan sosial yang cukup fenomenal tentang poligami. Masalah poligami dianggap sebagai tema besar, sehingga sangat menarik untuk diteliti melalui tanggapan atau respon pembacanya. Hal itu penting, karena melalui respons pembaca dapat diketahui kualitas dan nilai novel tersebut. Dengan begitu pula dapat dipahami dan diperoleh hikmah, pelajaran, yang bermakna serta bermanfaat dalam kehidupan.

\section{METODE PENELITIAN}

Penelitian ini bersifat sinkronis, oleh sebab itu metode analisis yang digunakan adalah analisis deskriptif. Metode ini digunakan untuk memaparkan respons pembaca pada suatu masa tertentu yang dititikberatkan pada aspek emosional pembaca. Data yang dianalisis adalah respons atau tanggapan pembaca ditinjau berdasarkan aspek emosionalnya terhadap novel Surga yang Dirindukan 2 karya Asma Nadia.

Sumber data berasal dari pembaca selaku responden berjumlah 15 orang yang dikelompokan atas kategori sosial masing-masing, yakni; Alumni sejumlah 2 orang dan Mahasiswa Aktif S-1 sejumlah 13 orang serta dikelompokkan berdasarkan jenis kelamin, masing-masing yakni; 2 orang responden laki-laki dan 13 orang responden perempuan. Adapun 15 responden tersebut berasal dari Jurusan Pendidikan Bahasa dan Sastra Indonesia, Universitas Negeri Gorontalo. Koleksi data penelitian dijaring melalui instrumen berupa angket yang mengandung beberapa pernyataan terakit dengan aspek emosional pembaca, seperti berikut ini.

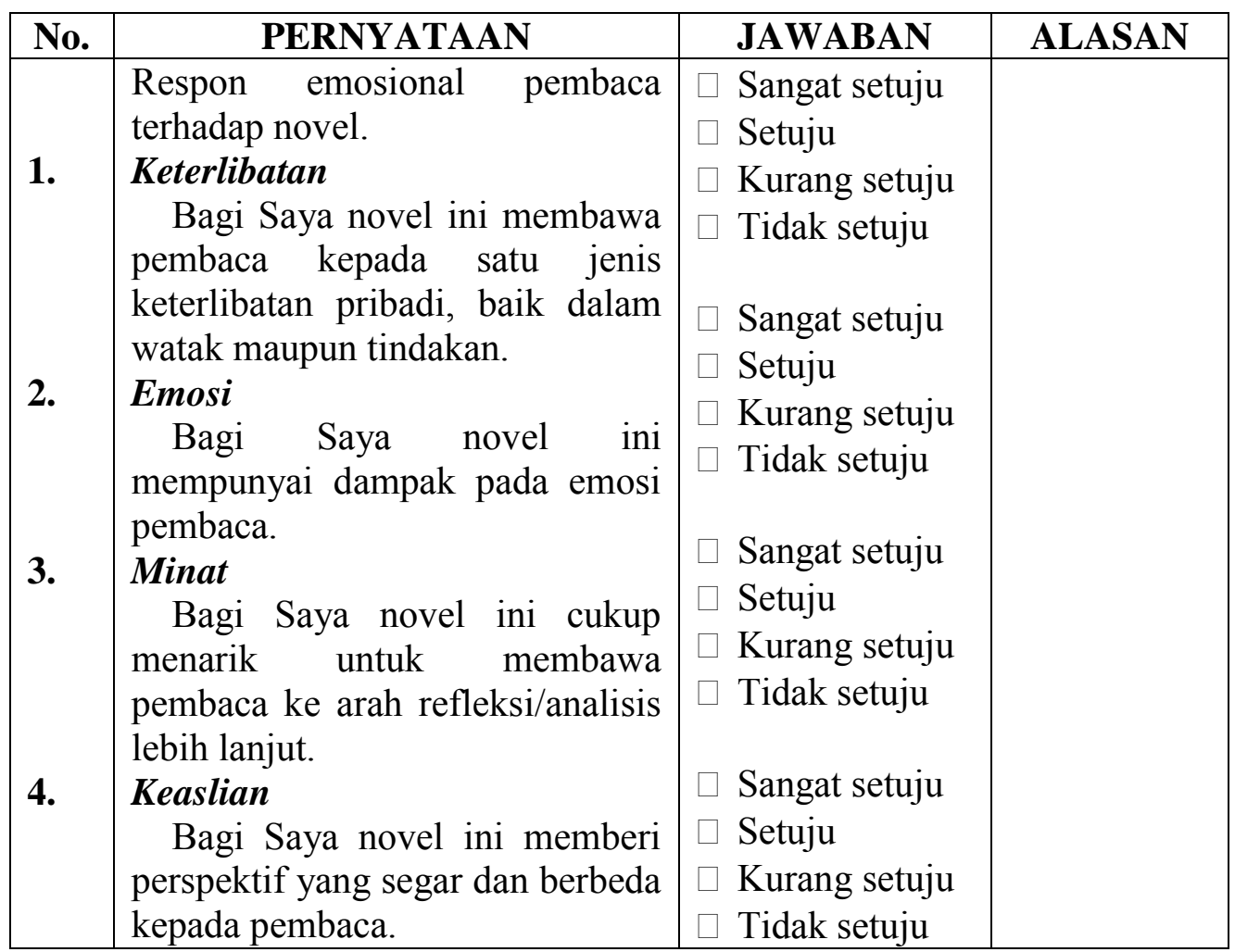




\begin{tabular}{|l|l|l|l|}
\hline 5. & Suka Cita & \\
Bagi Saya novel ini jenis & $\square$ Sangat setuju & \\
membangkitkan ketegangan & $\square$ Setuju \\
6. $\quad \begin{array}{l}\text { Kemampuan untuk percaya } \\
\text { Bagai Saya novel ini dapat } \\
\text { dipercaya oleh pembaca. }\end{array}$ & $\square$ Kurang setuju \\
\end{tabular}

Data penelitian dianalisis dengan cara: (1) mengidentifikasi; (2) mengklasifikasi; (3) mendeskripsikan; (4) menganalisis; dan (5) menarik kesimpulan sementara tentang respons pembaca terhadap novel Surga yang Dirindukan 2 karya Asma Nadia.

\section{HASIL DAN PEMBAHASAN}

Respons emosional pembaca terhadap novel Surga yang Dirindukan 2 karya Asma Nadia akan dipaparkan berdasarkan 6 unsur emosional pembaca sesuai batasan Rian T. Segers. Enam unsur tersebut menyangkut unsur keterlibatan, emosi, minat, keaslian, suka cita, dan kemampuan untuk percaya., seperti berikut ini.

\section{Respons Emosional Pembaca Ditinjau dari Unsur Keterlibatan}

Respons emosional pembaca pada setiap unsur tersebut akan diuraikan berikut. Berdasarkan hasil penelitian, respons pembaca terhadap unsur keterlibatan diperoleh hasil sebagai berikut. Ditinjau dari kategori status sosial, diketahui dua orang rersponden yang tergolong sebagai Alumni memilih jawaban yang sama yakni; kurang setuju (KS), 13 orang responden yang tergolong sebagai Mahasiswa Aktif (S-1) masing-masing; 2 orang memilih sangat setuju (SS), 8 orang memilih setuju (S), 2 orang memilih kurang setuju (KS), dan 1 orang memilih tidak setuju (TS). Selanjutnya pada kategori jenis kelamin, 2 orang lakilaki memilih jawaban yang sama yakni kurang setuju (KS), 13 orang responden wanita masing-masing; 2 orang memilih sangat setuju (SS), 8 orang memilih setuju (S), 2 orang memilih kurang setuju (KS), dan 1 memilih tidak setuju (TS). Berdasarkan pilihan tersebut, dapat dinyatakan bahwa respons emosional pembaca ditinjau dari unsur keterlibatan memiliki variasi tanggapan.

\section{Respons Emosional Pembaca Ditinjau dari Unsur Emosi}

Respons emosional pembaca ditinjau dari unsur emosi, diperoleh hasil berikut ini. Tanggapan responden berdasarkan kategori status sosial, terdapat 2 orang responden yang dikelompokkan sebagai Alumni memilih jawaban yang sama yakni; setuju (S), 13 orang responden Mahasiswa Aktif (S-1) diketahui 6 orang memilih sangat setuju (SS), 5 orang memilih setuju (S), dan 2 orang memilih kurang setuju (KS). Selanjutnya, pada kategori jenis kelamin, 2 orang laki-laki memilih jawaban yang berbeda yakni; 1 orang sangat setuju (SS) dan 1 orang memilih setuju (S), sedangkan 13 orang responden wanita masing-masing; 6 orang memilih sangat setuju (SS), 6 orang memilih setuju (S), dan 1 orang 
memilih kurang setuju (KS). Berdasarkan pilihan tersebut, dapat dinyatakan bahwa respons pembaca ditinjau dari unsur emosi memiliki variasi tanggapan.

\section{Respons Emosional Pembaca Ditinjau dari Unsur Minat}

Respons emosional pembaca ditinjau dari unsur minat, diperoleh hasil berikut ini. Ditinjau dari kategori status sosial, sejumlah 2 orang responden Alumni memilih jawaban yang sama, yakni setuju (S), 13 orang responden Mahasiswa Aktif (S-1) masing-masing; 5 orang memilih sangat setuju (SS), 7 orang memilih setuju (S), dan 1 orang memilih tidak setuju (TS). Berdasarkan kategori jenis kelamin, diketahui 2 orang responden laki-laki memilih jawaban yang sama yakni setuju (S), 13 orang responden wanita masing-masing; 5 orang memilih sangat setuju (SS), 7 orang memilih setuju (S), dan 1 orang memilih tidak setuju (TS). Berdasarkan pilihan tersebut, dapat dinyatakan bahwa respons emosional pembaca ditinjau dari unsur minat memiliki variasi tanggapan.

\section{Respons Emosional Pembaca Ditinjau dari Unsur Keaslian}

Respons emosional pembaca terhadap unsur keaslian, diperoleh hasil berikut ini. Berdasarkan kategori status sosial, terdapat 2 orang responden Alumni memilih jawaban yang berbeda, yakni 1 orang setuju (S) dan 1 orang kurang setuju (KS), 13 orang responden Mahasiswa Aktif (S-1) masing-masing; 5 orang memilih sangat setuju (SS), 5 orang memilih setuju (S), dan 3 orang memilih kurang setuju (KS). Selanjutnya pada kategori jenis kelamin, diketahui 2 orang resonden laki-laki memilih jawaban yang berbeda yakni; 1 orang setuju (S) dan 1 orang kurang setuju (KS), selanjutnya 13 orang responden wanita masing-masing; 5 orang memilih sangat setuju (SS), 5 orang memilih setuju (S), dan 3 orang memilih kurang setuju (KS). Berdasarkan pilihan tersebut, dapat dinyatakan bahwa respons emosional pembaca ditinjau dari unsur keaslian memiliki variasi tanggapan.

\section{Respons Emosional Pembaca Ditinjau dari Unsur Suka Cita}

Respons emosional pembaca ditinjau dari unsur suka cita, diperoleh hasil berikut ini. Ditinjau dari kategori status sosial, 2 orang responden Alumni memilih jawaban yang sama yakni; setuju (S), sedangkan 13 orang responden Mahasiswa Aktif (S-1) masing-masing; 3 orang memilih sangat setuju (SS), 7 orang memilih setuju (S), 2 orang memilih kurang setuju (KS) dan 1 orang tidak setuju (TS). Selanjutnya pada kategori jenis kelamin, 2 orang responden laki-laki memilih jawaban yang sama yakni setuju (S), serta 13 orang responden wanita masing-masing; 3 orang memilih sangat setuju (SS), 7 orang memilih setuju (S), 2 orang memilih kurang setuju (KS) dan 1 tidak setuju (TS). Berdasarkan pilihan tersebut, dapat dinyatakan bahwa respon emosional pembaca ditinjau dari unsur suka cita memiliki variasi tanggapan.

Respons Emosional Pembaca Ditinjau dari Unsur Kemampuan untuk Percaya

Respons emosional pembaca pada unsur kemampuan untuk percaya, diperoleh hasil berikut ini. Tanggapan responden yang termasuk ke dalam kategori status sosial Alumni sejumlah 2 orang memilih jawaban yang berbeda yakni; 1 orang sangat setuju (SS) dan 1 orang setuju (S), sedangkan 13 orang responden 
Mahasiswa Aktif (S-1) masing-masing; 2 orang memilih sangat setuju (SS), 5 orang memilih setuju (S), 4 orang memilih kurang setuju (KS) dan 2 orang tidak setuju (TS). Selanjutnya pada kategori jenis kelamin, diketahui 2 orang laki-laki memilih jawaban yang berbeda yakni; 1 orang sangat setuju (SS) dan 1 orang setuju (S), selanjutnya 13 orang responden wanita masing-masing; dua orang memilih sangat setuju (SS), enam orang memilih setuju (S), empat orang memilih kurang setuju (KS) dan satu orang memilih tidak setuju.

Berdasarkan paparan hasil di atas, dapata dinyatakan bahwa respons emosional pembaca terhadap novel ini sangat bervariasi. Semua responden memberikan tanggapan yang berbeda-beda pula terhadap novel Surga yang Dirindukan 2 karya Asma Nadia. Di dalam penelitian ini, perbedaan tanggapan tersebut terlihat pada unsur kemampuan untuk percaya, keterlibatan, dan suka cita. Secara emosional responden yang berstatus sosial mahasiswa lebih banyak tidak percaya tehadap masalah yang diangkat oleh pengarang dalam novel ini, dibandingkan dengan responden yang berstatus sarjana. Selanjutnya, tanggapan responden laki-laki dan perempuan terhadap novel ini juga memiliki perbedaan yang signifikan. Sebagian besar responden wanita tidak setuju dengan poligami yang dilakukan oleh tokoh Pras. Sebaliknya, secara emosional responden laki-laki justru memberikan tanggapan yang sangat mendukung sikap tokoh Pras yang dihadirkan oleh pengarang di dalam novel tersebut. Perbedaan tanggapan responden pada semua kategori seperti itu memiliki kualitas alasan yang berbedabeda. Hal ini menggambarkan bahwa faktor emosional antara responden yang sudah sarjana dan masih mahasiswa berbeda akibat adanya perbedaan kedewasaan dan intensitas pengalaman emosional yang berbeda-beda pula. Perbedaan itu memberikan penguatan bahwa setiap karya sastra berpeluang dapat ditanggapi oleh semua kalangan pembaca sesuai pertimbangan emosional atau perasaan masing-masing terhadap unsur-unsur yang terdapat di dalam karya sastra, termasuk novel yang telah diteliti ini.

\section{PENUTUP}

Berdasarkan hasil penelitian dan pembahasan, maka dapat disimpulkan bahwa respons emosional pembaca terhadap novel Surga yang Dirindukan 2 karya Asma Nadia terdapat perbedaan tanggapan yang signifikan. Perbedaan tersebut mengindikasikan bahwa setiap pembaca memiliki otoritas tersendiri di dalam merespons cerita novel. Otoritas tersebut memberikan peluang adanya perbedaan tanggapan pembaca di dalam menyambut sebuah karya sastra yang dihadirkan pengarang di tengah-tengah publik. Semakin adanya variasi tanggapan atau respons pembaca yang berbeda-beda, maka dapat dinyatakan bahwa karya tersebut semakin berkualitas, termasuk novel yang telah diteliti ini.

\section{REFERENSI}

Forster, E.M. 1955. Aspect of The Novel. New York: Harcourt Inc.

Kuiper, Kathleen. 2004. Prose: Literary Terms and Concept. New York: Britanica Publishing.

Nurgiyantoro, Burhan. 2010. Teori Pengkajian Fiksi. Yogyakarta: Gadjah Mada University Press. 
Pradopo, Rachmat Djoko. 2013. Beberapa Teori Sastra, Metode Kritik, dan Penerapannya. Yogyakarta: Pustaka Pelajar.

Priatni, Endah Tri. 2010. Membaca Sastra dengan Ancangan Literasi Kritis. Jakarta: Bumi Angkasa.

Segers, Rien T. 2000. Evaluasi Teks Sastra (Terjemahan Suminto A. Sayuti) Yogyakarta: Adicita.

Widodo, J. dan Ekarini S. 2009. Pola Penerimaan Teks (Estetika nResepsi) Cerpen Indonesia Mutakhir Siswa dan Sistem Pembelajaran Apresiasi Cerpen di SMU Kota Malang. Bestari. No 42. Hal. 106-121. 